from those of his trade in Europe. He first took my altitude by a quadrant, and then with rule and compasses described the dimensions and outlines of my whole body, all of which he entered upon paper; and in six days brought my clothes very ill-made, and quite out of shape, by happening to mistake a figure in the calculation. But my comfort was, that I observed such accidents very frequent, and little regarded."

The moral of this is obvious. Though it may not be necessary for an ophthalmic surgeon to have a quadrant, rule, and compasses, among his instruments, we must endeavour to gauge the size of the lens to be extracted and make our section of sufficient size to allow of its exit with a minimum of damage to the parts involved. The ustal error is for the section to be too small, and it is of small comfort, at the moment of finding our section to be of insufficient size, to think of the number of our colleagues who have been landed in the same plight through an error in calculation.

\title{
INTERNATIONAL OPHTHALMOLOGICAL CONFERENCE
}

EARLY in ()ctober the small committee nominated by Mr. E. Treacher Collins in virtue of a resolution passed at the General Meeting of English-speaking Ophthalmologists in July, 1925, sent out a general notice to Ophthalmological Societies and Ophthalmologists in all parts of the world, asking them to nominate two delegates from each country to confer on the question of the re-establishment of International Congresses, and on other matters of International Ophthalmological interest. The response to that notice has been widespread, and already all the principal countries of the world have indicated their approval of the project, and, in the great majority of cases, have named their delegates.

The arrangements which have been provisionally made, at present, are for the committee to meet at The Hague on Tuesday, July 12, on the invitation of the Netherlands Ophthalmological Society.

Mr. E. Treacher Collins will attend as ('onvener of the conference. The delegates nominated are:

Argentine - - - - Prof. Dr. Enrique B., Demaria. Prof. Dr. Raúl Argañaraz.

Austria - - - $\quad$ Dr. Adalbert Fuchs. Prof. Dr. Josef Meller.

Belgium - - - - Dr. Henri Coppez.

Dr. Léon Weekers. 


\begin{tabular}{|c|c|c|c|c|}
\hline BULGARIA & - & - & - & $\begin{array}{l}\text { Prof. Dr. C. Pascheff. } \\
\text { Dr. Slavoff. }\end{array}$ \\
\hline ChINA - & - & - & - & Dr. T. P. Lee. \\
\hline \multicolumn{3}{|c|}{ CZECHO-SlovaKIa } & - & $\begin{array}{l}\text { Dr. A. Elschnig. } \\
\text { Prof. Lešer. }\end{array}$ \\
\hline DENMARK & - & - & - & $\begin{array}{l}\text { Dr. K. K. K. Lundsgaard. } \\
\text { Dr. Chr. F. Bentzen. }\end{array}$ \\
\hline FINLAND & - & - & - & $\begin{array}{l}\text { Dr. Y. G. Lindberg. } \\
\text { Prof. V. Grônholm. }\end{array}$ \\
\hline FRANCE & - & - & - & $\begin{array}{l}\text { Dr. Morax. } \\
\text { Dr. Terrien. }\end{array}$ \\
\hline GERMANY & - & - & - & $\begin{array}{l}\text { Herrn. Prof. Dr. Axenfeld. } \\
\text { Herrn. Prof. Dr. Wessely. }\end{array}$ \\
\hline \multicolumn{2}{|c|}{ GREAT BRITAIN } & - & - & $\begin{array}{l}\text { Sir John Parsons. } \\
\text { Mr. Leslie Paton. }\end{array}$ \\
\hline HUNGARY & - & - & - & $\begin{array}{l}\text { Prof. Emile de Grósz, M.D. } \\
\text { Prof. L. de Blaskovich, M.D. }\end{array}$ \\
\hline JAPAN - & - & - & - & $\begin{array}{l}\text { Prof. Oguchi. } \\
\text { Prof. S. Ishihara. }\end{array}$ \\
\hline \multicolumn{2}{|c|}{ NETHERLANDS } & - & - & $\begin{array}{l}\text { Prof. Dr. G. F. Rochåt. } \\
\text { Prof. Dr. J. van der Hoeve. }\end{array}$ \\
\hline NORWAY & - & - & - & $\begin{array}{l}\text { Prof. Dr. Hagen. } \\
\text { Dr. Med. Malling, with }\end{array}$ \\
\hline \multicolumn{4}{|c|}{ as Substitutes, if necessary } & $\begin{array}{l}\text { Dr. Med. Schiötz. } \\
\text { Dr. Med. Gjessing. }\end{array}$ \\
\hline ROUMANIA & - & - & - & $\begin{array}{l}\text { Dr. C. Pandelescu. } \\
\text { Dr. N. Rásvan. }\end{array}$ \\
\hline SPAIN - & - & - & - & $\begin{array}{l}\text { Dr. M. Marquez. } \\
\text { Dr. F. Poyales. }\end{array}$ \\
\hline SWEDEN & - & - & - & $\begin{array}{l}\text { Prof. Albin Dalén, M.D. } \\
\text { Prof. Fritz Ask, M.D. }\end{array}$ \\
\hline SWITZERLA & & - & - & $\begin{array}{l}\text { Prof. J. Gonin. } \\
\text { Dr. Ernst Pflüger. }\end{array}$ \\
\hline UNITED ST & ATES & - & - & $\begin{array}{l}\text { Dr. Arnold Knapp. } \\
\text { Dr. G. E. de Schweinitz, with } \\
\text { Dr. W. R. Parker. }\end{array}$ \\
\hline
\end{tabular}

The following countries have intimated their intention of taking part, but have not yet nominated their delegates : Cuba, Poland, Yugo-Slavia, Italy.

No reply has, so far, been received from : Brazil, Chile, Egypt, Greece, Peru, Portugal, Russia, Venezuela. 